\title{
POLIGAMI DALAM ISLAM
}

\section{Baso Mufti Alwi}

\begin{abstract}
ABSTRAK
Jauh sebelum islam datang, praktek poligami memang telah ada, bahkan jumlah isteri bisa membengkak hingga belasan. Dari fakta ini membuktikan praktek ini terus terpelihara hingga kini dengan berbagai pembenaran dan legitimasi kultural, sosial, ekonomi, dan agama. Poligami telah menjadi bagian gaya hidup laki-laki dan karenanya di lingkungan tertentu praktek ini telah membudaya. Bila melihat variabel-variabel poligami dalam al-Qur'an, maka ada tiga poin penting yang dapat ditarik, yaitu pertama, memberikan kesempatan kepada laki-laki untuk berpoligami. Kedua peringatan atau warning kepada suami untuk harus berlaku adil. Ketiga, adanya ketidakmampuan laki-laku untuk dapat berperilaku adil di antara istri-istrinya sekalipun berusaha keras unutk itu. Ini artinya bila dilakukan komparasi atas berbagai ayat, kesimpulannya adalah satu ayat membolehkan poligami, sementara dua ayat lainnya justru (seakan-akan) ingin menafikkan terwujudnya syarat adil. Ayat yang membolehkan pun pada konteksnya berbicara tentang perlindungan terhadap yatim piatu dan janda korban perang.
\end{abstract}

Kata kunci : Poligami, Adil, Hukum, Tuntunan 


\section{A. Pendahuluan}

Poligami merupakan salah satu persoalan dalam perkawinan yang paling banyak dibicarakan sekaligus kontroversial. Satu sisi poligami ditolak dengan berbagai macam argumentasi baik yang bersifat normatif, psikologis bahkan sangat bersinggungan dengan ketidakadilan gender. Mereka berpendapat meskipun ada indikasi kebolehan poligami, namun itu bertujuan menghindari perilaku tidak adil dalam mengelolah harta anak yatim, itupun disertai persyaratan harus mampu berbuat adil terhadap isteri-isteri yang dinikahi. Sementara berbuat adil bukanlah hal mudah dan bahkan menurut mereka mustahil manusia mampu melakukannya. ${ }^{1}$ Bagi penentang Islam sendiri ada kecenderungan mengklaim poligami adalah bukti ajaran Islam dalam bidang perkawinan yang sangat diskriminatif terhadap wanita. Mereka menganggap poligamilah salah satu penyebab kemunduran dan keterbelakangan dunia Islam.

Pada sisi lain, poligami dikampanyekan karena dianggap memiliki sandaran normatif yang tegas dan dipandang sebagai salah satu alternatif untuk menyelesaikan fenomena selingkuh dan prostitusi. Menurut golongan ini, selain ada aturannya dalam nas, Rasulullah SAW sendiri secara aktual telah mempraktekkannya. Praktek poligami yang dilakukan merupakan bagian dari tat aturan poligami yang dilakukan Rasulullah merupakan bagian dari tata aturan poligami $^{2}$. Dengan kata lain, poligami bagi mereka mampu memberikan problem solving terhadap persoalan perzinaan, prostitusi, pergaulan bebas, perawan tua, dan persoalan kemasyarakatan lain yang berkenaan dengan perlindungan terhadap wanita. Pada umumnya, untuk melanggengkan poligami, mereka merumuskan pra kondisi yang mebolehkan praktek poligami tersebut antara lain isteri sakit serius, istri mandul, isteri tidak waras, isteri lemah dan tua sehingga tidak mampu mengurus kehidupan rumah tangga, dan lain sebagainya. ${ }^{3}$

Dalam dunia Islam sendiri, muncul diskursus apakah konsep poligami dalam QS. al-Nisa' [4]: $3^{4}$ berlaku secara normatif atau kontekstual. Dari itulah kedua

\footnotetext{
${ }^{1}$ Abdurrahman I. Doi, Women in Syari'ah (Islamic Law) (Malaysia: A.S. Noordeen, 1992), h.55

${ }^{2}$ Yusuf Qardawi, Fatwa-fatwa Kontemporer (Jakarta: Gema Islam, 1995), h. 687-688

${ }^{3}$ Abdurrahman I, Doi Women in Syari'ah (Islamic Law) (Malaysia: A.S. Noordeen, 1992), h. 52

و ان حفتم الا تقططوا في اليتمى فا نكحو اما طلب لكم من النساء مثنى و ثلث وربع فان خفتم الاتعدلوافواحدة 4 او ماماكت ايمانكن ذلك ادنى الاتعاوا
} 
diskursus ini sampai sekarang ditemukan berbagai ketentuan dan kontrol terhadap poligami dalam perundang-undangan negara muslim, yang menurut polarisasi Tahir Mahmood ada enam bentuk kontrol terhadap poligami, yaitu (1). Menekankan ketentuak berlaku adil sebagaimana ditetapkan dalam al-Qur'an. (2). Memberi hak kepada isteri untuk menyertakan pernyataan anti poligami dalam surah perjanjian perkawinan. (3). Harus memperoleh izin lembaga peradilan. (4). Hak menjelaskan dan mengontrol dari lembaga perkawinan kepada pihak yang akan berpoligami. (6). Memberikan sanksi pidana bagi pelanggar aturan poligami. $^{5}$

Dan dapat dicatat bahwa hampir semua negara Islam dan negara muslim membolehkan poligami. Hal ini terefleksi dalam undang-undang perkawinan masing-masing negara yang "terkesan setengah" hati untuk tidak membolehkan poligami, namun hanya bersifat minimalisir terjadinya praktek poligami dengan upaya mempersulit prosedurnya. Tercatat hanya Tunisia-lah yang melarang secara tegas praktek poligami. ${ }^{6}$ Sementara negara-negara Pakistan, Maroko, Sudan, Indonesia, dan lainnya pada dasarnya masih mebolehkan poligami.

Ketidak pahaman sebagian orang untuk berpoligami akan makna dan substansi aturan-aturan tersebut, kadang kala menjadikan orang yang berpoligami mengambil jalan pintas dengan menikah secara sirri atau tidak dicatatkan sebagimana yang diatur dalam undang-undang . praktek kawan sirri ini bisa berakibat pada tidak terjaminnya hak-hak yang timbul dari suatu perkawinan tersebut di depan hukum.

\section{B. Pengertian Poligami dan Ruang Lingkupnya}

Poligami berasal dari bahasa Yunani, penggalan kata poli/polus yang berarti banyak, sementara gamein/gamos berarti kawin atau perkawinan. Memahami kata ini, maka sah untuk dikatakan bahwa poligami adalah perkawinan banyak yang jadi tidsk terbatas. $^{7}$

\footnotetext{
5 Tahir Mahmood, Family Law Reform in The Muslim World (New Delhi: The Indian Law Institue: 1972), h. 275-278

${ }^{6}$ Rubya Mehdi, The Islamization of the Law in Pakistan (Surrey: Curzon Press, 1994), h. 162. Atho Mudzhar, Membaca Gelombang Ijtihad: Antara Tradisi dan Liberasi (Yogyakarta: Titian Ilahi Press, 1998), h. 183. David Pearl, A Textbook on Muslim Personal Law (USA: Croom Helm, 1987), h. 82

${ }^{7}$ Labib M.Z, Pembelaan Umat Muhammad (Surabaya: Bintang Pelajar, 1986), h. 15
} 
Dalam Kamus Bahasa Indonesia, pengertian poligami tidaklah seperti yang lazim dipahami, yaitu seorang suami beristeri lebih dari satu orang pada waktu yang bersamaan. Poligami dalm kamus ini adalah "Sistem perkawinan yang salah satu pihak memilki/mengawini beberapa orang lawan jenisnya dalam waktu yang bersamaan." Sedangkan yang lazim dipahami sebagai poligami itu disebut sebagai poligini. Poligini adalah "Sistem perkawinan yang membolehkan seorang laki-laki memiliki beberapa wanita sebagai isterinya diwaktu bersamaan”. Untuk wanita disebut poliandri.

Dalam tulisan ini, dipakai pengertian poligami yang lazim dipahami, yaitu seorang laki-laki mempunyai lebih dari satu isteri pada waktu yang bersamaan. Dalm pengertian ini tidak dapat dicantumkan jumlah isteri dalam berpoligami karena ada yang membatasi sampai empat orang dan lebih dari sembilan orang. ${ }^{8}$ Perbedaan ini muncul karena perbedaan penafsiran tentang QS. al-Nisa' [4]: 3. ${ }^{9}$ Meskipun demikian poligami dengn batasan empat orang isteri nampaknya didukung oleh bukti sejarah yaitu larangan Rasulullah SAW, atas kasus Gailan yang ingin mengawini wanita lebih dari empat orang. Denga demikian jika ada keinginan suami untuk menambah isteri lagi, maka salah satu dari empat yang itu harus di ceraikan sehingga jumlahnya tetap sebanyak empat orang isteri. ${ }^{10}$

\section{Landasan Normatif}

\section{Al-Qur'an}

Ayat-ayat yang berhubungan dengan poligami terdapat dalam QS. alNisa' [4]:3 dan 129. Pada ayat 3 dalam surah tersebut:

Terjemahannya :

"Dan jika kamu punya alasan takut kalau kamu tidak dapat bertindak secara adil kepada anak-anak yatim, maka kawinilah wanita dari anatara mereka (yang lain) yang sah untuk kamu, dua, tiga, empat; tapi jika kamu takut bahwa kamu tidak dapat memperlakukan mereka secara adil, maka nikahilah satu...".

\footnotetext{
${ }^{8}$ Pendapat yang membolehkan poligami lebih dari empat orang isteri di anut oleh Mazhab Zahiriah.

${ }^{9}$ Bella Dauran, The Limits of Poligami in Islam, Journal of Islamic and Comparatid Law (t.tp: tmp, 1969), h. 21-26

${ }^{10}$ Abdul Azis Dahlan, [et al.], Ensiklopedi Hukum Islam, Vol.4, (Cet.1; Jakarta: PT Icthiar Baru van Hoeve, 2001), h. 1186
} 
Ayat ini diturunkan segera setelah Perang Uhud berakhir (4 H/626 M). Saat itu umat islam banyak yang gugur di medan pertempuran dan dibebani oleh banyaknya anak yatim, janda, dan tawanan perang yang ada. Untuk memelihara mereka dari perbuatan yang tidak diinginkan, Allah swt, membolehkan untuk mengawini mereka. Tetapi jika mereka merasa takut akan menelantarkan mereka dan tidak sanggup memelihara harta anak yatim tersebut, maka Allah swt membolehkan mencari wanita lain untuk dikawini sampai empat orang.

Kendatipun secara eksplisit al-Qu'an menggaris bawahi bahwa memenuhi prinsip adil sebagaimana yang disebutkan di dalam ayat tersebut sulit untuk dicapai. Hal ini sebagaimana disebutkan dalam ayat yang lain :

Selanjutnya pada surah yang sama ayat 129 berbunyi :

Terjemahannya:

“ Dan tidak akan ada kekuatan dalam diri kamu untuk memperlakukan isteri-isterimu secara adil, meskipun kmau ingin sekali melakukannya, dan oleh karena itu, janganlah kamu terlalu cenderung kepada yang satu sehingga mengabaikan yang lain, membiarkannya dalam keadaan seperti ini mempunyai atau tidak mempunyai suami”.

Pada intinya ayat teresebut menyatakan bahwa bagaimanapun usaha seseorang untuk berbuat adil, tidak akan dapat mencapai keadilan yang sesungguhnya.

Menurut Asghar, dua ayat diatas menjelaskan betapa al-Qur'an begitu berat untuk menerima institusi poligami, tetapi karena hal itu tidak bisa diterima dalam situasi yang ada maka al-Qur'an membolehkan. Ayat ini sebenarnyabukan dari kebolehan, tetapi bagaimana berlaku adil terhadap anak yatim ketika mengawinni mereka. As-Sarakhsi menyatakan kebolehan poligami dan mensyaratkan pelakunya harus berlaku adil. Al-Kasani, wajib berlaku adil terhadap isteri-isterinya. As- Syafi'iy juga mensyaratkan keadilan diantara para isteri, keadilan hanya menyangkut urusan fisik semisial mengunjungi isteri di malam atau siang hari. ${ }^{11}$

${ }^{11}$ Amiur Nuruddin dan Azhari Akmal, Hukum Perdata Islam di Indonesia : Studi Kritis Perkembangan Hukum Islam dari Fikih, UU No. 1/1974 sampai KHI (Jakarta: Kencana, 2004), h.161 
Jika disederhanakan, pandangan normatif al-Qu'ran yang selanjutnya diadopsi oleh ulama-ulama fiqh, setidaknya ada dua persyaratan yang dimiliki suami. Pertama, seorang laki-laki yang akan berpoligami harus memiliki kemampuan dana yang cukup unutk membiayai berbagai keperluan dengan bertambahnya isteri yang dinikahi. Kedua, seorang laki-laki harus memperlakukan semua isterinya dengan adil. Tiap isteri harus diperlakukan sama dalam memenuhi hak perkawinan serta hak-hak lain. ${ }^{12}$

\section{Hadis}

Ahmad al-Wahidi an-Naisaburi (w. 468 H/1076 M) dalam bukunya Asbab al-Nuzul menceritakan bahwa pada waktu itu ada seorang laki-laki yang punya anak yatim itu punya beberapa harta, maka kata Nabi saw "Jangan ia nikahi karena mengharapkan hartanya, lalu ia disakiti dan disiasiakan kesehatannya. Karena itu, jika takut tidak berlaku adil terhadap anak yatim itu, kawinilah wanita lain dan diperbolehkan ia membatalkan niat untuk kawin dengan anak yatim itu" (HR. Muslim dari Abi Kuraibah dari Abi Usama dari Hisyam). ${ }^{13}$

Dalam hadis lain yang di riwayatkan oleh Abu Hurairah, bahwa Rasulullah saw melarang laki-laki untuk melamar wanita yang sudah dilamar oleh sudaranya, atau membeli apa yang sudah dibeli saudaranya. Janganlah seorang wannita meminta untuk menceritakan saudara wanitanya (madunya) supaya cukup baginya apa yang ada di dalam bejana dan piringnya. Sesungguhnya rezekinya ada di dalam tanggungan Allah swt,. (Muttafaq 'alaih). Dalam hadis lain, Rasulullah saw., bersabda: "Tidak diperbolehkan menikahi seorang wanita dengan menceraikan yang lainnya”. (HR.Ahmad).

Dari hadis Abu Hurairah di atas di dapatkan adanya larangan seorang wanita untuk memberi syarat supaya menceritakan saudarinya. Sementara hadis selanjutnya juga ada larangan yang menunjukkan kerusakan yang diakibatkannya. Karena dia memberi syarat untuk menceraikan saudarinya maka batallah pernikahannya, batal hak-haknya dan juga hak-hak

\footnotetext{
${ }^{12}$ Ibid

${ }^{13}$ Abdul Azis Dahlan, [et al.], Ensiklopedi, h. 1186.
} 
isterinya. Sebagaimana ketika dia mensyaratkan untuk menceraikannya, maka batallah jual belinya. ${ }^{14}$

\section{Perundang-undangan}

Kendatipun Undang-undang Perkawinan Nomor 1 tahun 1974 menganut asas monogami, seperti yang terdapat dalam pasal 3 yang menyatakan, "Seorang pria hanya boleh mempunyai seorang isteri dan seorang wanita hanya boleh mempunyai seorang suami, namun pada bagian lain menyatakan bahwa dalam keadaan tertentu poligami dibenarkan. ${ }^{15}$ Ini menandakan bahwa asas yang dianut oleh undang-undang perkawinan sebenarnya, bukan asa yang dianut oleh undang-undang perkawinan sebenarnya bukan asas monogami mutlak melainkan disebut monogami terbuka atau monogami tidak mutlak. Karenanya poligami ditempatkan pada status hukum darurat atau keadaan yang luar biasa (extra ordinary circumstance). Apalagi poligami tidak semata-mata kewengan penuh suami, tetapi atas dasar izin dan campur tangan dari hakim pengadilan ${ }^{16}$. Seorang suami yang akan berpoligami terlebih dahulu memenuhi syarat-syarat yang ditentukan dalam pasal 5 ayat 1, yaitu (1). Adanya persetujuan dari isteri/isteri. (2). Adanya kepastian bahwa suami mampu menjamin keperluan hidup isteri-isteri dan anak-anak mereka. (3). Adanya jaminan bahwa suami akan berlaku adil terhadap isteri dan anak-anak mereka.

Bila melihat alasan poligami bedasarkan isi pasal 4 (lihat footnote nomor 23) maka tampaknya alasan-alasan tersebut bernuansa fisik, kecuali alasan tidak dapat melahirkan keturunan. Ada kesan bahwa seorang suami tidak memperoleh kepuasan yang maksimal dari isterinya. Perbedaannya dengan pasal 5 ayat 1 diatas, adalah pada pasal 4 disebut dengan persyaratan alternatif yang artinya salah satu harus ada untuk dapat mengajukan

\footnotetext{
${ }^{14}$ Karim Hilmi, Ta'addu al-Zaujat fi al-Adyan. Diterjemahan oleh Munirul Abidin dengan judul Poligami: Berkah atau Musibah?, (Jakarta; Senayan, 2007), h. 102

15 Pasal 4, "Seorang suami yang akan beristeri lebih dari seorang apabila:

a. Isteri tidak dapat menjalankan kewajibannya sebagai isteri

b. Isteri mendapat cacat badan atau penyakit yang tidak dapat disembuhkan

c. Isteri tidak dapat melahirkan keturunan.

${ }^{16}$ Pasal 3 ayat 2, "Pengadilan dapat memberikan izin kepada seorang suami untuk beristeri lebih dari seorang apabila dikehendaki oleh pihak-pihak yang bersangkutan ". Hal ini diatur juga dalam PP No.9 tahun 1975 pasal 40,41,42,43, dan 44.
} 
permohonan poligami. Sementara pasal 5 adalah persyaratan kumulatif di mana seluruh syarat harus dapat dipenuhi oleh suami yang akan berpoligami.

Dalam perspektif Kompilasi Hukum Islam, masalah poligami diatur pada bagian IX dengan judul "Beristeri lebih dari satu orang" pasal 55 sampai pasal 59. Tidak berbeda dengan UU Perkawinan di atas, KHI juga pada dasarnya menganut prinsip monogami, namun peluang yang diberikan untuk berpoligami juga terbuka lebar. Kewenangan pengadilan juga turut berperan besar dalam pemberian izin poligami sehingga keputusan dapat diajukan banding atau kasasi. ${ }^{17}$

Dalam perspektif metodologis, pengaturan ketentuan hukum mengenai poligami dimaksudkan untuk mewujudkan ketertiban umum dan kemaslahatan yaitu terwujudnya cita-cita dan tujuan perkawinan itu sendiri. Karena itu persoalan-persoalan yang memungkinkan akan menjadi penghalang bagi terwujudnya tujuan perkawinan tersebut harus dihilangkan atau setidaknya dikurangi. ${ }^{18}$ In merupakan langkaj preventif dan antisipatif untuk menjaga keutuhan sebuah keluarga.

\section{Tuntunan Poligami}

\section{Keadilan dalam Berpoligami}

Salah satu hal yang sering dipertanyakan orang adalah mengapa lakilaki cenderung untuk berpoligami. Tidak sedikit pula yang menjawab bahwa mereka berpoligam dengan alasan menjalankan kewajibannya untuk berlaku adil. Itulah sebabnya, mengapa para isteri membenci poligami karena banyak didapatkan suami yang menikah dengan wanita lain akan berpaling pada isteri barunya dengan lebih mencintai dan menyayanginya dari isteri lamanya.

Menurut Karim, orang yang mengambial syariat poligami harus juga menjalankan syariat-Nya untuk berlaku adil diantara isteri-isterinya. Bila

${ }^{17}$ Pasal 59 KHI: "Dalam hal isteri tidak mau memberikan persetujuan, dan permohonan izin untuk beristeri lebih dari satu orang berdasarkan atas salah satu alasan tentang pemberian izin setelah memeriksa dan mendengar isteri yang bersangkutan di persidangan Pengadilan Agama, dan terhadap penetapan ini isteri atau suami dapat mengajukan banding atau kasasi

${ }^{18}$ Ahmad Rofiq, Hukum Islam di Indonesia (Jakarta: Raja Grafindo Persada, 1998), h. 176 
mereka tidak melakukan hal itu, maka mereka telah melanggar hukum Allah swt untuk berlaku adil terhadap isteri-isterinya. ${ }^{19}$

Menurut Karim, adil yang dimaksud adalah membagi tempat secara adil (sama rata antara isteri yang satu dengan isteri yang lain). Waktu bersama mereka, kenyamanan, serta tidak mengkhususkan antara satu dengan yang lainnya. Sejak generasi muslim pertama, masa Rasulullah dan para sahabat, mereka memberikan sandal yang sama, warna, bentuk, dan modelnya untuk isteri-isterinya di rumah sehingga tidak terjadi olok-olokan di antara mereka. ${ }^{20}$

Para ulam fiqh cenderung memahami keadilan dalam arti kuantitatif yang bisa di ukur dengan angka-angka. Dengan kata lain keadilan pada halhal yang bersifat material dan terukur. Implikasinya poligami lebih mudah dilakukan dan menjadi sesuatu lembaga yang bisa dijalankan. Sementara Muhammad Abduh, yang mewakili ulama kontemporer, mengartikan keadilan yang bersifat kualitatif seperti kasih sayang,cinta, perhatian yang semuanya tidak bisa diukur dengan angka-angka. ${ }^{21}$

Dalam konteks KHI, persyaratan adil dalam berpoligami harus dapat dibuktikan didepan pengadilan. Seorang suami harus mampu membuktikan dirinya bahwa dia adalah seorang yang berlaku adil dan tetap akan berlaku adil ketika perkawinan poligami itu berlangsung. ${ }^{22}$

Hak-hak dan kehormatan para wanita muslimah telah dilembagakan denan aturan-aturan Allah swt, tentang bagaimana cara memperlakukan wanita, Allah swt. berfirman:

ؤ عا شر ؤهن با لمعر ؤف

Terjemahannya: “.... pergauilah mereka (kaum wanita) dengan cara yang ma'ruf..."

Ayat diatas menunjukkan kepada kaum laki-laki untuk memelihara isteri-isterinya dengan cara yang adil. Implikasinya jelas langsung dan benar. Para isteri harus diperlakukan dengan cara yang sebaik-baiknya. Bahkan, bila seorang laki-laki ternyata sudah bosan dengan isterinya atau tidak

${ }^{19}$ Karim Hilmi, Ta'addu, h. 34.

${ }^{20} \mathrm{Ibid}$,. H. 37.

${ }^{21}$ Amiur Nuruddin dan Azhari Akmal, Hukum Perdata, h. 172-173

${ }^{22}$ Ibid. 
menyukainya lagi, dia tidak diiperbolehkan memperlakukannya secara tidak baik sebab bisa jadi, meskipun dia tidak menyukai salah satu sifatnya, dia menemukan sifat-sifat lain yang baik dan mengimbangi sifat yang tidak disukainya itu. Bila seorang laki-laki yang memiliki lebih dari seorang isteri mencurahkan rasa cinta lebih berat kepada salah seorang diantara keduanya, secara lahiriah dia harus memperlakukan semuanya secara baik tanpa meninggalkan sama sekali salah seorang diantara keduanya.

ؤلا تعضاؤ هن لتد هبؤ / ببعض ما ا تبيتهؤ هن

Terjemahannya: "Jangan kamu tinggalkan dia (isterimu) sama sekali dan kamu biarkan dia terombang-ambing tidak menentu".

Demikian halnya bagi suami untuk tidak boleh lebih cenderung cinta secara mencolok kepada salah seorang isteri karena dapat menimbulkan kecemburuan sakit hati sehingga dapat menimbulkan permusuhan antara isteri-isteri. Meskipun demikian, menurut Jamilah Jones, laki-laki tidak mampu untuk mengendalikan emosi-emosinya dalam pengetahuan yang tuntas. Artinya, emosi yang muncul dari dirinya ketika dia sama sekali tidak mengharapkan mereka, dan dari situlah dia tidak dapat menetapkan secara jujur kemana hatinya condong. ${ }^{23}$

Oleh sebag itu, tinjuan al-Qur'an tentang poligami tidak hanya ditinjau dari segi ideal atau baik buruknya. Tetapi harus juga dilihat dari sudut pandang penetapan hukum dalam aneka kondisi yang mungkin terjadi. Sehingga wajarlah suatu perundang-undangan apalagi agama yang bersifat universal dapat berlaku untuk setiap waktu dan tempat dalam rangka mempersiapkan ketentuan hukum yang boleh jadi terjadi pada suatu ketika. ${ }^{24}$

\section{Jumlah Batasan Berpoligami}

Poligami adalah sistem yang telah lahir di Arab sebelum Islam datang. Praktek ini dilakukan semata-mata untuk kebutuhan biologis dan beberapa

${ }^{23}$ Jamilah Jones dan Abu Aminah Bilal Philips, Plural Marriage in Islam. Diterjemahkan oleh Machnun Husein dengan judul Monogami dan Poligini dalam Islam (Cet, II: Jakarta: Srigunting, 2001), h. 57.

${ }^{24}$ Quraish Shihab, Tafsir al-Misbah: Pesan, Kesan, dan Keserasian al-Qur'an (Jakarta: Lentera Hati, 2000), h.324 
aspek masyarakat. Islam yang datang kemudian tidak serta melarang umatnya untuk berpoligami dan tidak pula menganjurkan secara mutlak tanpa ada batasan. Islam membatasi dengan ikatan keimanan yang terkandung dalam alQur'an dengan cara membatasi hanya dengan empat orang wanita saja. ${ }^{25}$

Ibnu Qayyim al-Jauziyah berpendapat bahwa jumlah batasan poligami sampai empat orang sesuai dengan tabiat, hukum dan jumlah musim dalam setahun. Suami yang yang menikah dengan satu orang isteri berarti ia tetap bersabar dari tiga hal. Tiga adalah awal urutan jumlah yang pertama, dan Allah swt., telah mengaitkan banyak hukum dengan jumlah tiga, seperti memberikan toleransi kepada para muhajirin untuk tinggal di Makkah setelah haji 3 hari, seorang wanita diperbolehkan bersolek untuk selain suaminya tiga kali, memberi kesempatan kepada orang yang terpaksa menalak isterinya sebanyak tiga kali kemudian kembali. Ini adalah rahmat dan kemaslahatan. ${ }^{26}$

Membatasi laki-laki untuk menikah dengan empat wanita merupakan usaha yang paling dekat untuk dapat beraku adil daripada memiliki lebih dari itu. Sebab kasih sayang seorang suami tidak akan bisa berbuat adil meskipun mereka sudah berusaha sekuatnya.

Ijma telah menghasilkan keputusan yang mengaharamkan poligami lebih dari empat wanita. Jumhur ulama menggunakan hadis Rasulullah saw., sebagai hujjah yakni hadis yang mengatakan bahwa Rasulullah saw., menyuruh umat islam yang memiliki isteri lebih dari empat untuk memilih empat dari mereka dan menceraikan yang lainnya.

Diantara sahabat yang disuruh untuk menceraikan isteriny adalah Haaris bin Qaais al-Asmi yang memiliki delapan Isteri, Mas'ud bin Amir bin Mut'ab, Ma'ud bin Amir, Urwah bin Mas'ud, dan lainnya. Mereka semua memiliki Isteri lebih dari empat orang. ${ }^{27}$

\footnotetext{
${ }^{25}$ Karim Hilmi, Ta'addu....., h. 17.

${ }^{26} \mathrm{Ibid}$, h. 47.

${ }^{27}$ Ibid., h. 25-26.
} 
Menurut Wahba Zuhaili, setelah Rasulullah wafat, tidak ditemukan alasan lain dari sahabat yang membolehkan poligami lebih dari empat orang isteri. Hal yang senada juga dikemukakan oleh Muhammad 'Ali asy-Syaukani. Menurut Wahba Zuhaili, alasan pembatasan berpoligami sampai empat orang karena pada lahirnya kemampuan suami dalam berlaku adil, membayar nafkah, pembagian waktu dan sebabnya hanya sampai empat orang isteri dengan pengaturan mingguan dalam satu bulan. Lebih dari itu, disangsikan suami tidak memberikan perhatian sempurna dan tidak sanggup menunaikan hak-hak isteri-isterinya. Karena itu kebolehan berpoligami setidaknya harus memenuhi dua persyaratan. Pertama, berlaku adil antara isteri-isteri dan anak-anaknya. Kedua, kesanggupan membayar nafkah atau belanja nikah rumah tangganya sesuai dengan sabda Rasulullah saw ., tentang perlunya biaya nikah (al-ba'ah) bagi calon suami. ${ }^{28}$

Terhadap poligami yang dilakukan Rasulullah saw., yang beristeri melebihi batasan yang diperkenakan bagi umatnya, merupakan salah satu pengecualian yang didasarkan pada kehendak Allah swt., dan hikmah-Nya. Menurut Karim Hilmi ada beberapa sebab tidak ada batasan dalam poligami Rasulullah saw. : 29

1. Karena Rasulullah saw,. Berpoligami sebelum turunya surat An-Nisaa' yang memberikan batasan poligami, dan Allah swt. Mengecualikan poligaminya dan mengkhususkannya dengan pengecualian tersebut. Kecuali jika Allah swt.,.

Menyuruhnya untuk menceraikannya. Jika salah satu dari mereka ingin bercerai, Rasulullah saw., pun menceraikannya. Barangsiapa ingin tetap bersamanya Beliau pun terus menaunginya. (Al-Ahzaab [33]: 2829)

2. Allah swt., melarang Rasulullah saw., untuk menceraikan salah satu isterinya setelah mereka memilih tetap bersama Beliau dan melarang menikah kembali kecuali dengan mereka. (Al-Ahzaab [33]: 52)

${ }^{28}$ Abdul Azis Dahlan, [et al], Ensiklopedi, h. 1186-1187

${ }^{29}$ Karim Hilmi, Ta'add..., h. 120-122 
3. Allah swt., menghormati isteri-isteri Rasulullah setelah mereka memilih untuk teteap bersamanya, kemudian mereka dikenal dengan ummahaat al-mu'miniin. (Al-Ahzaab [33]: 6). Begitu juga mereka dilarang untuk menikah kembali setelah Rasulullah saw., meninggal dunia karena mereka adalah ummahaat al-mu 'miniin. (Al-Ahzaab [33]: 53).

\section{Pembagian Nafkah (bathin) antara Isteri Muda dan Isteri Tua}

Terhadap Isteri yang baru dinikahi (yang masih gadis) diberikan waktu luang untuk berkenalan lebih intim dengan suaminya karena baru pertama kali menikah dan melakukan hubungan seksual. Sedangkan bagi wanita yang sebelumnya pernah menikah (janda) dalam banyak hal sudah tidak asing lagi dengannya dalam mengenali teman hidupnya yang baru. ${ }^{30}$ Walaupun telah ditentukan selama tujuh hari bagi Isteri yang masih gadis, tetapi waktu tujuh hari itu juga boleh diberikan kepada pengantin janda agar perkawinan dan hubungan seksualnya lebih terasa sebagai pengalaman baru sebagaimana pengantin yang masih gadis. ${ }^{31}$ Kesempatan ini diberikan karena ada beberapa alasan diantaranya perkawinan sebelumnya hanya berlangsung sangat pendek atau bahkan belum sempat melakukan hubungan seksual. Atau boleh juga karena tenggan waktu antara perkawinan sebelumnya dengan yang sekarang sangat lama. ${ }^{32}$

Perubahan waktu bersama dengan isteri (janda) dari tiga hari menjadi tujuh hari menyebabkan sang suami harus menambah waktu bergilirnya genap tujuh hari untuk ister-isterinya yang lain.Abuu Bakr AlHaaris menuturkan bahwa pada pagi hari setelah Rasulullah saw,. Menikah dengan Ummu Salamah, Beliau mengatakan kepadanya:

${ }^{30}$ Al-Husain ibn Mas'ud al-Bagaawi, Syarhu al-Sunnah, Jilid IX (Beirut: al-Maktabah alIslamiyah, 1973), h. 156

${ }^{31}$ Lihat Ibn Hajar al-Asqalaani, Tahzib al-Tahzib, Juz. VII, (Beirut: Daar al-Fikr.1984), h. 34

32 Jamilah Jones dan Abu Aminah, Plural ..., h. 68-70 
"Jangan merasa bahwa engkau tidak penting diantara bangsamu, karena bila kamu menghendaki, saya akan menghabiskan waktu tujuh hari (bersamamu) dan tujuh hari bersama isteri-isteri saya yang lain atau bila kamu menghendaki, saya akan menghabiskan waktu tiga hari bersamamu dan sesudah itu membagi rata waktu bergilir saya” Dia menjawab : "Berikan saja untukku tiga hari”.

Oleh karena itu, setelah isteri yang baru bersam dengan suami, maka suami wajib membagi rata waktu bergilirnya kepada isteri-isterinya yang lain dengan melakukan undian untuk menentukan dengan siapakah dia akan memulai gilirannya.

\section{Giliran Terhadap Para Isteri}

Seorang suami yang memiliki tekad paling kuat dan paling luhur untuk membagi waktu bergilirnya secara adil dan bijaksana terhadap IsteriIsterinya tentu akan mengalami dilema bagaimana memulai pembagian waktu bergilmya. Dalam banyak hal ia akan menemui beberapa persoalan untuk dipertimbangkan manakah isteri pertama yang mendapat giliran. Karena itu keputusan yang tepat bisa dianggap sebagai perlakuan yang tidak memihak terehadap isteri-isteri yang lain. Karena itu sebenarnya tidak ada metode yang paling tepat dalam menyelesaikan masalah ini.

Bila melihat metode undian (quru'ah), sebagai metode yang sederhana, yang pernah dicontohkan Rasulullah, maka pada prinsipnya tidak menetapkan hak-hak terlebih dahulu kepada isteri. Jadi, jika seorang suami menikah lagi, maka ia harus segera menata ulang kembali pembagian waktu bergilirnya kepada para isterinya tersebut. Misalnya, seorang suami memiliki isteri baru yang ketiga, maka ia harus mengundi dua kali untuk menentukan giliran siapa yang pertama dengannya dan berikutnya. Jika seandainya memiliki isteri keempat, maka undian itu diubah lagi sebagai suatu keadilan.

Salah satu cara yang biasa dilakukan para ulama dalam menentukan pilihan adalah suami menulis angka-angka pada kertas undian yang menunjukan urutan mlam, kemudian dikocok untuk diambil satu persatu oleh 
isteri. ${ }^{33}$ Penarikan seperti ini dilakukan kapan saja bila suami akan melakukan pembagian waktu bergilir secara adil.

Mesikpun demikian ada pengecualian atas penetapan waktu bergilir ini manakalaseorang suami bersama dengan isteri yang baru dinikahi. Mereka berdua diberikan kesempatan untuk tinggal bersama bersama selama tiga hari (bila isteri sudah janda) atau tujuh hari lamanya (bila isteri itu masih perawan). ${ }^{34}$ Setelah berakhirnya masa bersama itu lalu dibuat kembali aturan tentang periode bergilir tersebut terhadap para isteri.

Pembagian waktu bergilir biasanyan dilakukan berdasarkan malam karena fakta menunjukan bahwa malam hari adalah waktu dimana orang berhenti bekerja dan beristirahat. Pembagian malam dan siang ini ditetapkan dan ditata oleh Allah swt., sesuai dengan sifat manusia. ${ }^{35}$ Dengan demikian seorang suami membagi malamnya diantara para isterinya sedangkan siangnya adalah miliknya untuk mencari penghasilan. Terhadap suami yang berprofesi sebagai penjaga malam, maka siang harinyalah yang harus dibagi rata diantara para isterinya. Pembagian ini juga harus dilakukan terhadap isteri yang tidak bisa melakukan hubungan seksual sekalipun misalnya sakit, sedang haid, manapouse dan lain sebagainya, kecuali isteri tersebut memberikan haknya kepada isteri yang lain. ${ }^{36}$ Hal ini didasarkan atas pemenuhan kebutuhan psikologis dan emosional wanita dari teman hidupnya, yaitu suami. Sebab kebutuhan tersebut dalam banyak hal semakin membesar bila para wanita (atau suami sendiri) mendapatkan halangan sementara atau halangan tetap. Para suami juga dituntut untuk membagi rata waktu yang dimilikinya meskipun mereka sendiri dalam keadaan sakit, bila para isteri menghendakinya.

\section{E. Kesimpulan}

${ }^{33}$ Muhammad Ibnu Qudaamah, Al-Mugnii, Juz. VII (Mesir: Maktabah al-Qaahirah, 1968), h. 301-302. Hal yang perlu diperhatikan adalah bahwa idealnya setiap isteri mempunyai tempat tinggal tersendiri dimana suami dapat mengunjunginya karena begitulah cara Rasulullah membagi waktu bergilirnya. Berdasarkan fakta ini maaka, seorang suami hendaknya tidak menempatkan isteri-isterinya di satu rumah bila mereka tidak setuju dengan penataan bersama atau rumahnya dibagi menjadi beberapa bagian yang terpisah satu sama lain sehingga menjadi seperti dua tempat tinggal.

34 Jamilah Jones dan Abu Aminah, Plural, h. 69.

${ }^{35}$ QS. al-An'am [6]: 96. QS. al-Naba'[78]: 11

${ }^{36}$ Saudah, salah satu istri Rasulullah memberikan hak bergilirnya kepada madunya, Aisyah. 
Berdasarkan pembahasan diatas,maka dapat disimpulkan:

1. Bahwa pembatasan isteri sampai empat orang saja adalah final menurut para ulama, hal ini didukung oleh perintah Rasulullah kepada para sahabatnya yang memiliki isteri sepuluh orang untuk memilih empat orang saja dan menceraikan selebihnya.

2. Terhadap pembagian nafkah (bathin) antara isteri muda dan tua memiliki perbedaan dimana isteri muda diberikan waktu yang lebih lama daripada isteri yang tua. Kondisi ini antara lain tidak lepas dari pengalaman hidup baru bagi isteri muda. Meskipun demikian, pembagian ini sifatnya fleksibel manakala isteri yang tua merelakan waktunya untuk diberikan kepada isteri yang tua.

3. Terhadap pembagian giliran terhadap isteri sangat didasarkan atas pemenuhan kebutuhan psikologis dan emosional wanita terhadap teman hidupnya, yaitu suami. Sebab kebutuhan tersebut dalam banyak hal semakin membesar bila para wanita (atau suami sendiri) mendapatkan halangan semsentara atau halangan tetap. Para suami juga dituntut untuk membagi rata waktu yang dimilikinya meskipun mereka sendiridalam keadaan sakit, bila para isteri menghendakinya. 


\section{DAFTAR PUSTAKA}

Akmal, Amiur Nuruddin dan Azhari. Hukum Perdata Islam di Indonesia: Studi Kritis Perkembangan Hukum Islam dari Fikih, UU No. 1/1974 sampai KHI, Jakarta: Kencana, 2004

Al-Asqalaaniy, Ibnu Hajaar. Tahzib, Juz. VII, Beirut: Daar al-Fikr, 1984

Al-Bagaawi, Al-Husain ibn Mas'ud. Syarhu al-Sunnah, Jilid IX, Beirut: AlMaktabah al-Islaamiyah, 1973

Dahlan, Abdul Aziz. [et al], Ensikopledi Hukum Islam. Vol.4, Jakarta: PT. Ichtiar Baru van Hoeve, 2001

Daura, Bella. "The Limits of Poligami in Islam" dalam Journal of Islamic and Comparatif Law, t.tp: tmp, 1969

Doi, Abdurrahman I. Women in Syari'ah (Islamic Law), Malaysia: A.S. Noordeen, 1992

Hilmi, Karim. Ta'addu al-Zaujaat fi al-Ayaan. (Diterjemahkan oleh Munirul Abidin dengan judul Poligami: Berkah atau Musibah?. Jakarta: Senayan, 2007

Mahmood, Tahir. Family Lam Reform in The Muslim World, New Delhi: The Indian Law Institute: 1972

Mehdi, Rubya. The Islamization of tteh Law in Pakistan, Surrey: Curzon Press, 1994 